\title{
COVID-19 CT Features: A Scoping Literature Review
}

Mahmoud S. Babiker

College of Applied Medical Science, Diagnostic Radiologic Technology Dept. Taibah University, Al-Madinah Al- Munawarah, KSA

DOI: $\underline{10.36347 / \text { sjams.2020.v08i08.001 }}$

| Received: 08.07.2020 | Accepted: 25.07.2020 | Published: 05.08.2020

*Corresponding author: Dr. Mahmoud S. Babiker, PhD

Email: mahsalih@yahoo.co.uk

Abstract

Original Research Article

Coronavirus disease (COVID-19) is a pandemic associated with high morbidity and mortality. Chest computerized tomography (CT) imaging has proven an essential role in diagnosing COVID-19 along with clinical and laboratory tests. This study was a scoping review of literature on several studies regarding COVID-19 CT features. The review indicated that pure ground-glass opacity (GGO), mixed GGO with consolidation, pure consolidation, and pleural effusion were the most common identified COVID-19 CT features. However, further studies regarding the association of COVID-19 CT features with age, gender, and chronic illness like diabetes and hypertension were recommended.

Keywords: COVID-19, computerized, tomography, features, imaging.

Copyright @ 2020: This is an open-access article distributed under the terms of the Creative Commons Attribution license which permits unrestricted use, distribution, and reproduction in any medium for non-commercial use (NonCommercial, or CC-BY-NC) provided the original author and source are credited.

\section{INTRODUCTION}

Coronavirus disease (COVID-19) is an infectious disease caused by a newly discovered coronavirus as stated by WHO [1]. The virus that causes COVID-19 is designated severe acute respiratory syndrome. [2] Radiology imaging has an important role in diagnosing COVID-19 along with other clinical and laboratory investigations. Some authors indicated that the imaging pattern of multifocal peripheral groundglass opacity (GGO), mixed GGO or consolidation with predominance in the lower lung $(\mathrm{S} 6,10)$, with more extensive mixed opacity than GGO and consolidation is highly suspicious of COVID-19 infection when considering an interval between symptom onset and computerized tomography (CT) examination of 7.61 (7) days [3].

Diffuse damage, edema, and transparent membrane formation of the lungs after the invasion are complications of COVID-19 infection, which is similar to pathological changes caused by SARS and MERS [4]. Zhou S et al. [5] have attributed the peripheral distribution of COVID-19 lesions to virus invasion of bronchioles and alveoli, causing inflammatory reactions which need the participation of immune cells, and added that the distribution of blood vessels and lymphatics rich in immune cells is more abundant in the peripheral and lower areas.

Chest CT would play an important supplemental role in diagnosing COVID-19 pneumonia even before getting the results of RT-PCR. [6] Typical
CT findings can help in the early screening of patients with the suspected disease and efficiently evaluate the extent of COVID-19 acute respiratory disease [7]. Li, Bingjie, et al. [8] have shown that CT imaging characteristics of COVID-19, mainly GGO and pulmonary consolidation, with prominent distribution in the posterior and peripheral part of the lungs.

The current scoping review aimed to answer the following question; what is the common COVID-19 - CT features that were identified during the Corona pandemic?

\section{MeTHODS}

The methods for the review follow the fivesteps framework of the scoping review proposed by Arksey and O’Malley [9].

Step 1: Identify the Research Question

The question for this review study is; what are the common COVID-19 computerized tomography (CT) features that were identified during the Corona pandemic?

Step 2: Find relevant studies

Studies were identified by using a systemic search of the PubMed electronic database. The period of selected studies was from February to June 2020. For the searching, the term (COVID-19) was used with the limitation of human studies and English language / or translated papers to English by Google. 
Step 3: Study selection

Titles and abstracts for all articles were reviewed, if the abstract contained insufficient information, then the full text was retrieved. Only human studies in COVID-19 CT features were included. Non-English studies were excluded except for which could be translated by the Google translation tool. Only studies with sufficient data about COVID19- CT features were included. The selection diagram and screening process are demonstrated in Figure1. The review included published articles from Feb. 20202 through July 2020.

\section{Step 4: Charting the data}

The data were extracted from each eligible article and all selected articles were summarized in tables/Figures. Extracted data included the journal name/abbreviation, the author \& title, date of the publication, and COVID-19 - CT features and their percentages. [See Tables $1 \& 2$ and Figure2].

Step 5: Collate, summarize, and report the results:

The review was organized according to COVID-19 CT findings and features.

\section{RESULTS}

A total of 295 articles were identified, of those, the reviewer selected 24 articles for direct relevance. 14 articles were included in this review according to their eligibility. The COID-19- CT findings have been grouped by the following features [Table 1]: pure GGO opacities (GGO), [pure GGO or with consolidation, or with reticular pattern], pure Consolidation, crazy paving pattern, interlobular thickening, adjacent pleura thickening, linear opacities, pleural effusion, nodules, lymphadenopathy, vascular thickening, and pericardial effusion.

\section{(GGO)}

Some authors $[10,11]$ have shown that opacity of the GGO may be attributed to alveolar wall collapse or alveoli filled with blood, pus, water, or cells. Five studies $[7,10,18,19,21]$ reported pure GGO in more than $70 \%$ of COVID-19 participants, ranged from (72 $86.1 \%)$. Seven studies [(13-17), 20, 22] reported this CT feature in $(35.3-59.9 \%)$ of the patients. Only one study [11] reported a low frequency of the GGO (15\%) of the patients. Ten studies [7, 11, 12, 14, 15, (17-20), 22] reported GGO with consolidation in different ranges from $(16.3-82.6 \%)$ of the patients. GGO associated with the reticular pattern was identified by four studies $[13,14,18,19]$ through a frequency of $(6-75 \%)$ of the patients.

[Figure3 represents a sample for CT findings].

\section{Pure Consolidation}

Previous study 11 proposed that increased lesion density, along with disease progression manifested as patchy consolidations in CVID-19 CT chest images. Twelve studies [7, 10, 11, 13, (15-22)] observed pure consolidation as a CT feature of COVID19. Five studies $[10,11,17,20,22]$ have shown low frequency of this feature (3-16.3\%), four studies $[7,13$, $15,21]$ identified consolidation in $(33.9-48.5 \%)$ of the patients, and three studies [16, 18, 19] demonstrated pure consolidation in above $50 \%$ of the patients (55$79 \%)$.

\section{Crazy paving pattern}

The crazy-paving pattern has been defined by some authors [23] as a linear pattern superimposed on a background of ground-glass opacity, resembling irregularly shaped paving stones. This feature was detected by six studies $[10,11,14,16,18,20]$ two studies $[10,11]$ demonstrated the low frequency of this feature $(6.4-12 \%)$ while, the four studies $[14,16,18$, $20]$ observed crazy paving pattern in high frequency $(58.1-89.4 \%)$

\section{Interlobular thickening}

Interlobular septal thickening represents pathology in the periphery of the pulmonary lobules (ie, the interlobular septa). 25 This feature has been demonstrated by six studies $[10,11,15,(19-21)]$. five of them $[11,15,(19-21)]$ identified the feature in $>50 \%$ of the patients $(52-76.9 \%)$. One study demonstrated low frequency $(37 \%)$.

\section{Adjacent pleura thickening}

This feature has been demonstrated by six studies. [(10-13), 15, 21] Three of these studies [11-13] observed adjacent pleural thickening in $<50 \%$ of the patients (24- 48.4\%). The other three 10, 15, 22 noted this feature in relatively high frequency $(56 \%$ $73.3 \%$ ).

\section{Linear opacities}

Eight studies have detected this feature. [7, 10, $(12-14), 18,19,22]$ of these five studies $[7,12,18,19$, 22] identified the feature in $<50 \%$ of the patients $(5.33 \%-48.5 \%)$. Three studies $[10,13,14]$ identified this feature in $>50 \%$ of the patients $(54.8 \%-61 \%)$.

\section{Pleural effusion}

This feature has been demonstrated by nine studies. [7, 10, (11-15), 18, 20] All these studies identified pleural effusion in relatively low frequencies (2-13.9\%) of the patients.

\section{Nodules}

Six studies $[7,11,12,16,17,20]$ have identified nodules in COVID-19 patients. They also, showed that this feature has been demonstrated in low frequency $(4.2-22.8 \%)$.

\section{Lymphadenopathy}

Lymphadenopathy has been detected by five studies [7, (10-12), 19]. These studies have indicated that this CT feature has a low incidence, it was observed only in (1-6\%) of the patients. 


\section{Vascular thickening}

Seven studies [7, (11-13), 15, 17, 20] have identified vascular thickening. Three studies [12, 13, 17] showed this feature in low frequency $(8-45.2 \%)$, and four studies $11,15,19,21$ indicated a high incidence of this feature in COVID-19 patients (64$82.4 \%)$.

\section{Pericardial effusion}

Only two studies [10, 19] have demonstrated pericardial effusion in very low frequency $(1-6 \%)$ of the patients.

Table-1: Basic data of the 14 selected studies

\begin{tabular}{|c|c|c|c|c|}
\hline $\begin{array}{l}\text { Study } \\
\text { number in the } \\
\text { reference list }\end{array}$ & $\begin{array}{l}\text { Journals } \\
\text { names/abbreviations }\end{array}$ & Authors/Title & $\begin{array}{l}\text { publication date/ } \\
\text { year and month }\end{array}$ & $\begin{array}{c}\text { Subjects } \\
\#\end{array}$ \\
\hline 7 & AJR Am J Roentgenol & $\begin{array}{l}\text { Zhao et al. Relation Between Chest CT Findings } \\
\text { and Clinical Conditions of Coronavirus Disease } \\
\text { (COVID-19) Pneumonia: A Multicenter Study }\end{array}$ & 2020 May & 101 \\
\hline 10 & $\begin{array}{l}\text { Eur J Nucl Med Mol } \\
\text { Imaging }\end{array}$ & $\begin{array}{l}\text { Xu et al. Imaging and Clinical Features of Patients } \\
\text { With } 2019 \text { Novel Coronavirus SARS-CoV-2 }\end{array}$ & $2020 \mathrm{Feb} 28$ & 90 \\
\hline 11 & J Transl Med & $\begin{array}{l}\text { Li et al. CT Imaging Changes of Corona Virus } \\
\text { Disease 2019(COVID-19): A Multi-Center Study } \\
\text { in Southwest China }\end{array}$ & $2020 \mathrm{Apr}$ & 125 \\
\hline 12 & Jpn J Radiol & $\begin{array}{l}\text { Fan et al. Imaging Characteristics of Initial Chest } \\
\text { Computed Tomography and Clinical } \\
\text { Manifestations of Patients With COVID-19 } \\
\text { Pneumonia }\end{array}$ & 2020 Jun & 150 \\
\hline 13 & AJR Am J Roentgenol & $\begin{array}{l}\text { Zhou et al. CT Features of Coronavirus Disease } \\
2019 \text { (COVID-19) Pneumonia in } 62 \text { Patients in } \\
\text { Wuhan, China }\end{array}$ & 2020 May & 52 \\
\hline 14 & Eur Radiol & $\begin{array}{l}\text { Zhou et al. Imaging Features and Evolution on CT } \\
\text { in } 100 \text { COVID-19 Pneumonia Patients in Wuhan, } \\
\text { China }\end{array}$ & 2020 May 21 & 100 \\
\hline 15 & $\begin{array}{l}\text { National library of } \\
\text { medicine }\end{array}$ & $\begin{array}{l}\text { Wu et al. Novel Coronavirus Pneumonia (COVID- } \\
\text { 19) CT Distribution and Sign Features] }\end{array}$ & 2020 April 12 & \\
\hline & & & & 130 \\
\hline 16 & Acad Radiol & $\begin{array}{l}\text { Guan et al. Imaging Features of Coronavirus } \\
\text { Disease } 2019 \text { (COVID-19): Evaluation on Thin- } \\
\text { Section CT }\end{array}$ & 2020 May & 53 \\
\hline 17 & $\begin{array}{l}\text { Chinese journal of } \\
\text { tuberculosis and } \\
\text { respiratory diseases }\end{array}$ & $\begin{array}{l}\text { Lu XF et al. Clinical Features and High Resolution } \\
\text { CT Imaging Evolution of Coronavirus Disease } \\
2019\end{array}$ & 2020 Jun & 141 \\
\hline 18 & J Infect & $\begin{array}{l}\text { Liu H et al. Clinical and CT Imaging Features of } \\
\text { the COVID-19 Pneumonia: Focus on Pregnant } \\
\text { Women and Children }\end{array}$ & 2020 May & 55 \\
\hline 19 & Radiology & $\begin{array}{l}\text { Song et al. Emerging } 2019 \text { Novel Coronavirus } \\
(2019-\mathrm{nCoV}) \text { Pneumonia }\end{array}$ & 2020 April & 51 \\
\hline 20 & AJR Am J Roentgenol & $\begin{array}{l}\text { Li Y et al. Coronavirus Disease } 2019 \text { (COVID-19): } \\
\text { Role of Chest CT in Diagnosis and Management }\end{array}$ & 2020 Jun & 51 \\
\hline 21 & $\begin{array}{l}\text { Zhonghua Yi Xue Za } \\
\text { Zhi }\end{array}$ & $\begin{array}{l}\text { Liu RR et al. CT Imaging Analysis of } 33 \text { Cases } \\
\text { With the } 2019 \text { Novel Coronavirus Infection }\end{array}$ & 2020 April & 33 \\
\hline 22 & Korean J Radiol & $\begin{array}{l}\text { Liu Z et al. Association Between Initial Chest CT } \\
\text { or Clinical Features and Clinical Course in Patients } \\
\text { With Coronavirus Disease } 2019 \text { Pneumonia }\end{array}$ & 2020 Jun & 72 \\
\hline Total & & & & 1392 \\
\hline
\end{tabular}


Table-2: CT features and their percentages for the selected studies

\begin{tabular}{|c|c|c|c|c|c|c|c|c|c|c|c|c|c|c|c|}
\hline \multirow[b]{2}{*}{ \# } & \multirow[b]{2}{*}{ CT features } & \multicolumn{14}{|c|}{ The selected studies \& COVID-19 CT features' percentages (\%) } \\
\hline & & St.1 & St.2 & St.3 & St.4 & St.5 & St.6 & St.7 & St.8 & St.9 & St.10 & St.11 & St.12 & St.13 & St.14 \\
\hline 1 & $\begin{array}{l}\text { Ground glass } \\
\text { opacities }\end{array}$ & 72 & 15 & - & 40.3 & 41.9 & 53.8 & 59.6 & 36.8 & 72 & 86.1 & 77 & 35.3 & 75.8 & 22.2 \\
\hline 2 & $\begin{array}{l}\text { GGO + } \\
\text { Consolidation }\end{array}$ & 0 & 47 & 82.67 & - & 43 & 46.2 & - & 16.3 & 43 & 64.4 & 59 & 54.9 & - & 23.6 \\
\hline 3 & $\begin{array}{l}\text { GGO + reticular } \\
\text { pattern }\end{array}$ & - & - & - & 62.9 & 58.1 & - & - & - & 6 & - & 75 & - & - & \\
\hline 4 & Consolidation & 13 & 3 & - & 33.9 & - & 46.2 & 63.8 & 16.3 & 79 & 43.6 & 55 & 5.9 & 48.5 & 8.3 \\
\hline 5 & $\begin{array}{l}\text { Crazy paving } \\
\text { pattern }\end{array}$ & 12 & 6.4 & 0 & - & 58.1 & - & 89.4 & - & 71 & - & - & 70.6 & & - \\
\hline 6 & $\begin{array}{l}\text { Interlobular } \\
\text { thickening }\end{array}$ & 37 & 52 & 0 & - & - & 76.9 & 0 & - & - & - & 75 & 70.6 & 54.5 & - \\
\hline 7 & $\begin{array}{l}\text { Adjacent pleura } \\
\text { thickening }\end{array}$ & 56 & 24 & 35.33 & 48.4 & - & 73.3 & 0 & - & - & - & - & - & 72 & - \\
\hline 8 & linear opacities & 61 & 0 & 5.33 & 54.8 & 58.1 & - & 0 & - & 6 & 48.5 & 22 & - & - & 41.7 \\
\hline 9 & Pleural effusion & 4 & 0 & 4 & 9.7 & 12.8 & 2.3 & 0 & - & 7 & 13.9 & 8 & 2 & - & - \\
\hline 10 & Nodules & 0 & 16 & 12 & - & - & - & 4.2 & 4.9 & - & 22.8 & - & 21.5 & - & - \\
\hline 11 & Lymphadenopathy & 1 & 13 & 1.33 & - & - & - & 0 & 0 & 0 & 1 & 6 & & - & - \\
\hline 12 & $\begin{array}{l}\text { Vascular } \\
\text { thickening }\end{array}$ & - & 64 & 8 & 45.2 & - & 76.9 & 0 & 34.04 & - & 71.3 & - & 82.4 & - & - \\
\hline 13 & $\begin{array}{l}\text { Pericardial } \\
\text { effusion }\end{array}$ & 1 & - & - & - & - & - & - & - & - & - & 6 & - & - & - \\
\hline
\end{tabular}

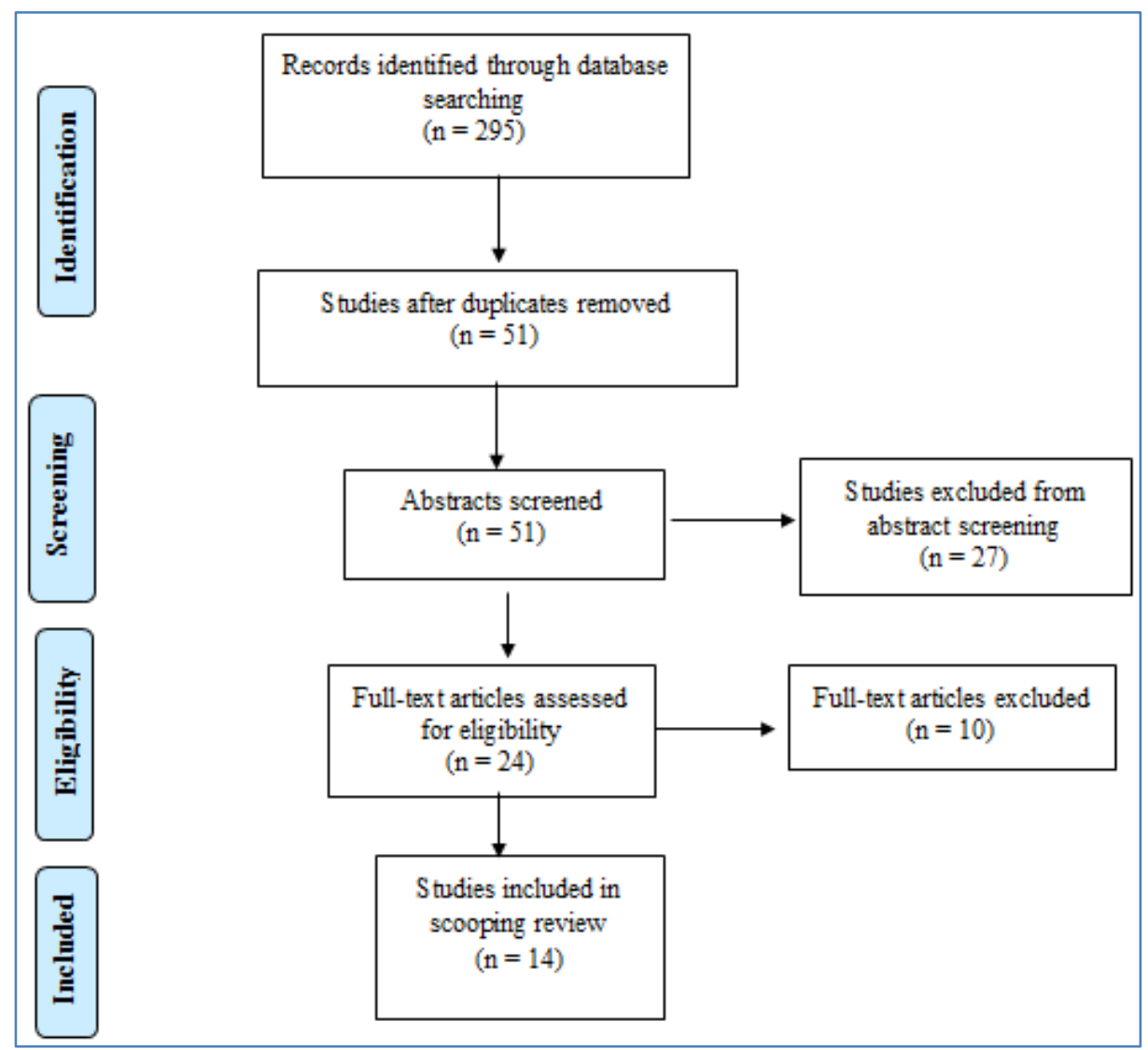

Fig-1: The Study flow diagram (modified flowchart of the selection and screening process) [2] 


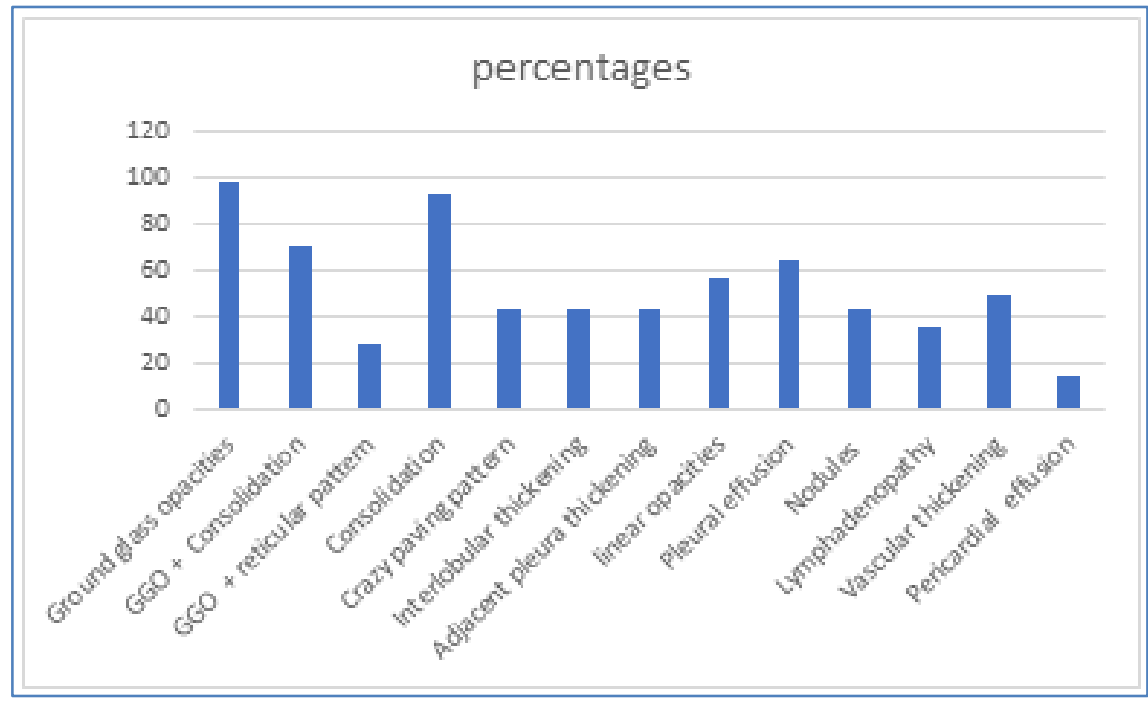

Fig-2: Percentages of COVID-19 - CT features according to the 14 selected studies
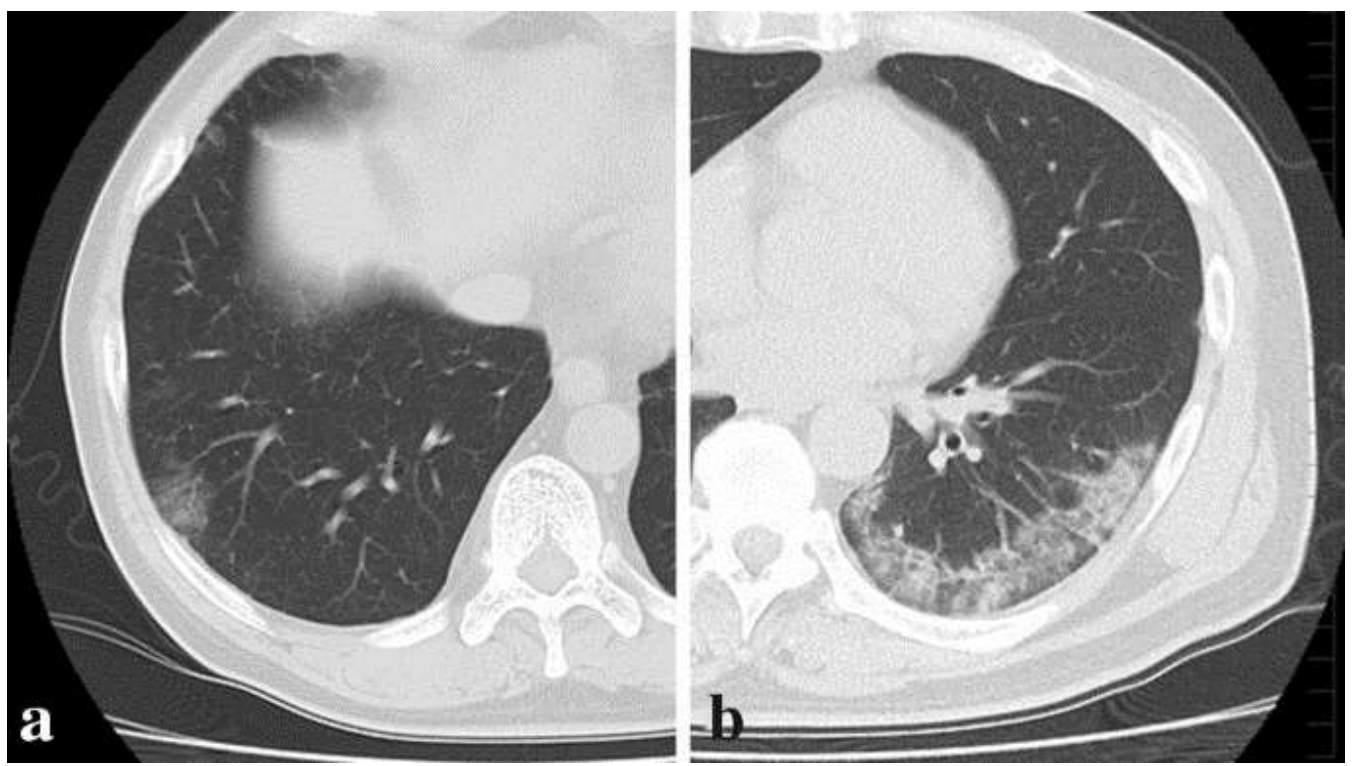

Fig-3: Typical CT findings in patients with COVID-19 pneumonia. a A transverse CT image in a 67-year-old man with fever (day 4). CT shows rounded, peripheral ground glass lesion in the right lower lobe. b CT image in a 56-year-old man presented with fever (day 11). CT shows peripheral glass opacities with superimposed fine reticular shadows in the left lower lobe[6]

\section{DISCUSSION}

The scoping review of several studies showed that COID-19 has multiple signs and features in a chest CT image. The results of this current review [See Figure2] distributed the identification of CT features in COID-19 patients as follow; pure GGO was observed by $>90 \%$ of the selected studies, consolidation was demonstrated by $>80 \%$ of the studies, mixed GGO with consolidation was detected by $>70 \%$ of the studies. Pleural effusion $>60 \%$, linear opacities, and vascular thickening were noted by around $50 \%$ of the studies. Crazy paving patterns, interlobular thickening, adjacent pleural thickening, and nodules were presented by around $40 \%$ of the studies.

Lymphadenopathy was noted in $<40 \%$ of the studies, while pericardial effusion was identified by only two studies (14\%). Regarding lesion distribution, patients with COVID-19 were more likely to have peripheral distribution, bilateral involvement, lower lung predominance, and multifocal distribution. [6, 7, 26] These results agree with the majority of currently selected studies [7, (10-14), (16-19), 22]. Some authors $[15,20,21]$ have indicated that COVID-19 lesions could be sub-pleural in distribution. The majority of the studies [7, (10-12), 18, 19, 22] have shown that COVID-19 lesions are usually multiple lesions however; Xia T et al. [27] demonstrated that some patients with COVID-19 infection could have an only solitary sub-centimeter ground-glass nodule on baseline chest CT images.

GGO or GGO with consolidation was the most common radiological features. Other common radiological features include interlobular septal thickening, crazy-paving pattern, air bronchogram/ traction bronchiectasis, halo sign/reverse halo sign, and 
pleural thickening. [25] Pleural effusion could be considered as a common COVID-19 CT feature, it was identified by $>60$ of the currently selected studies [See Figure2].

Variations were noted regarding the quantity of detected COVID-19 CT features among the studies. Some authors [7, 10, 11, 19] identified around nine features. Some studies [21, 22] have demonstrated only four features.

Li, Yang, et al. [28] showed that the chest CT imaging features and clinical manifestations of COVID19 in preschool children are atypical and various, and are relatively mild or moderate compared with adult patients. They added, it is difficult to distinguish the CT manifestations of COVID-19 pneumonia from those of other common pneumonia occurring in winter. Himoto, $\mathrm{Y}$ et al. [6] have proposed that rounded morphology of opacities was statistically associated with COVID-19 pneumonia, and it is useful in the differentiation of COVID-19 pneumonia from other respiratory diseases presenting with similar symptoms.

Yin, Zhilan, et al. [26] have provided another hypothesis, they suggested that to potentially aid in distinguishing between influenza A (H1N1) pneumonia and COVID-19 pneumonia, findings of bronchiectasis and pleural effusion may be used to identify patients with influenza A (H1N1) pneumonia and findings of linear opacification, crazy-paving sign, vascular enlargement, and pleural thickening to identify patents with COVID-19 pneumonia. With consideration of etiologic testing.

A small sample size of the review may be considered a limitation for this study.

\section{Conclusion}

The current scoping review concluded that $\mathrm{CT}$ imaging has a good contribution to COVID-19 diagnosis and management. Pure GGO, mixed GGO with consolidation, pure consolidation, and pleural effusion were the most common COVID-19 CT features. Further studies in testing the association of COVID-19 CT features with age and gender, and chronic illness like diabetes and hypertension were recommended.

\section{REFERENCES}

1. "Coronavirus." World Health Organization, World Health Organization, Available from www.who.int/health-topics/coronavirus.

2. McIntosh K. Coronavirus disease 2019 (COVID19): Epidemiology, virology, and prevention. Available from;

https://www.uptodate.com/contents/coronavirusdisease-2019-covid-19-epidemiology-virology-andprevention.
3. Yang W, Cao Q, Qin L. Clinical characteristics and imaging manifestations of the 2019 novel coronavirus disease (COVID-19): A multi-center study in Wenzhou city, Zhejiang, China. J Infect. 2020; 80(4):388-393.

4. Chen, Xing. "Dynamic Chest CT Evaluation in Three Cases of 2019 Novel Coronavirus Pneumonia." Archives of Iranian Medicine. 2020; 23(4): 277-280.

5. Zhou S, Zhu T, Wang Y, Xia L. Imaging features and evolution on CT in 100 COVID-19 pneumonia patients in Wuhan, China. Eur Radiol. Available from: http://dx.doi.org/10.1007/s00330-020-068796.

6. Himoto Y, Sakata A, Kirita, M. Diagnostic performance of chest CT to differentiate COVID19 pneumonia in non-high-epidemic area in Japan. Jpn J Radiol.2020; 38 (5): 400-406.

7. Zhao, Wei. "Relation between Chest CT Findings and Clinical Conditions of Coronavirus Disease (COVID-19) Pneumonia: A Multicenter Study." American Journal of Roentgenology. 2020; 214 (5): 1072-1077.

8. Li, Bingjie. "Diagnostic Value and Key Features of Computed Tomography in Coronavirus Disease 2019." Emerging Microbes \& Infections.2020; 9(1): 787-793.

9. Arksey H, O’Malley L: Scoping studies: towards a methodological framework. Int $\mathrm{J}$ Soc Res Methodol. 2005; 8(1): 19-32.

10. Xu X, Yu C, Qu J, Zhang L, Jiang S, Huang D. Imaging and clinical features of patients with 2019 novel coronavirus SARS-CoV-2. Eur J Nucl Med Mol Imaging. 2020; 47(5):1275-1280.

11. Li X, Zeng W, Li X, Chen H, Shi L, Li X, Xiang H, Cao Y, Chen H, Liu C, Wang J. CT imaging changes of corona virus disease 2019 (COVID-19): a multi-center study in Southwest China. Journal of translational medicine. $2020 \mathrm{Dec} ; 18: 1-8$.

12. Fan N, Fan W, Li Z, Shi M, Liang Y. Imaging characteristics of initial chest computed tomography and clinical manifestations of patients with COVID-19 pneumonia. Jpn J Radiol. 2020; 38(6):533-538.

13. Zhou S, Wang Y, Zhu T, Xia L. CT features of Coronavirus disease 2019 (COVID-19) pneumonia in 62 patients in Wuhan, China. AJR Am J Roentgenol. 2020; 214(6):1287-1294.

14. Zhou S, Zhu T, Wang Y, Xia L. Imaging features and evolution on CT in 100 COVID-19 pneumonia patients in Wuhan, China. Eur Radiol. Available from: http://dx.doi.org/10.1007/s00330-020-068796

15. Wu J, Feng CL, Xian XY, Qiang J, Zhang J, Mao QX, Kong SF, Chen YC, Pan JP. Novel coronavirus pneumonia (COVID-19) CT distribution and sign features. Zhonghua jie he he hu xi za zhi= Zhonghua jiehe he huxi zazhi= Chinese journal of tuberculosis and respiratory diseases. 2020 Mar 3;43:E030-. 
16. Guan CS, Lv ZB, Yan S, Du YN, Chen H, Wei LG, Xie RM, Chen BD. Imaging features of coronavirus disease 2019 (COVID-19): evaluation on thin-section CT. Academic radiology. 2020 Mar 20.

17. Lu XF, Gong W, Wang L, Li L, Xie BJ, Peng ZF, Zha YF. Clinical features and high resolution CT imaging evolution of coronavirus disease 2019. Zhonghua jie he he hu xi za zhi= Zhonghua Jiehe he Huxi Zazhi= Chinese Journal of Tuberculosis and Respiratory Diseases. 2020 Jun 1;43(6):50915 .

18. Liu H, Liu F, Li J, Zhang T, Wang D, Lan W. Clinical and CT imaging features of the COVID-19 pneumonia: Focus on pregnant women and children. J Infect. 2020; 80(5): 7-13.

19. Song F, Shi N, Shan F, Zhang Z, Shen J, Lu H, Ling Y, Jiang Y, Shi Y. Emerging 2019 novel coronavirus (2019-nCoV) pneumonia. Radiology. 2020 Apr;295(1):210-7.

20. Li Y, Xia L. Coronavirus disease 2019 (COVID19): Role of chest CT in diagnosis and management. AJR Am J Roentgenol. 2020; 214(6):1280-1286.

21. Liu RR, Zhu Y, Wu MY, Liu J, Ren R, Cao QL, Shen XH, Chen GQ, Li M. CT imaging analysis of 33 cases with the 2019 novel coronavirus infection. Zhonghua yi xue za zhi. 2020 Apr 1;100(13):100711.

22. Liu Z, Jin $\mathrm{C}$, Wu CC, Liang $\mathrm{T}$, Zhao H, Wang Y, Wang Z, Li F, Zhou J, Cai S, Zeng L. Association between Initial Chest CT or Clinical Features and Clinical Course in Patients with Coronavirus Disease 2019 Pneumonia. Korean Journal of Radiology. 2020 Jun;21(6):736.

23. De Wever W, Meersschaert J, Coolen J, Verbeken E, Verschakelen JA. The crazy-paving pattern: a radiological-pathological correlation. Insights into imaging. 2011 Apr 1;2(2):117-32.

24. Thrumurthy SG, Kearney S, Sissons M, Haider Y. Diffuse interlobular septal thickening in a coal miner. Thorax. 2010 Jan 1;65(1):82-4.

25. $\mathrm{Hu} \mathrm{L}$, Wang C. Radiological role in the detection, diagnosis and monitoring for the coronavirus disease 2019 (COVID-19). Eur Rev Med Pharmacol Sci. 2020 Apr 1;24(8):4523-8.

26. Yin Z, Kang Z, Yang D, Ding S, Luo H, Xiao E. A Comparison of Clinical and Chest CT Findings in Patients With Influenza A (H1N1) Virus Infection and Coronavirus Disease (COVID-19). American Journal of Roentgenology. 2020 Apr 10:1-7.

27. Xia T, Li J, Gao J, Xu X. Small Solitary GroundGlass Nodule on CT as an Initial Manifestation of Coronavirus Disease 2019 (COVID-19) Pneumonia. Korean J Radiol. 2020; 21(5): 545549.

28. Li Y, Cao J, Zhang X, Liu G, Wu X, Wu B. Chest CT imaging characteristics of COVID-19 pneumonia in preschool children: a retrospective study. BMC Pediatrics. 2020 Dec;20:1-8. 